\title{
EDUVELOP
}

Journal of English Education and Development

Volume 1, No. 1, September 2017

ISSN 2597-713X (print)

ISSN 2597-7148 (online)

\section{THE ENGLISH VOCABULARY ACQUISITION OF THE STUDENTS OF STATE JUNIOR HIGH SCHOOL 2 PAREPARE}

\author{
RAFIQA \\ English Education Department, Faculty of Social and Political Science \\ West Sulawesi University \\ Address. J1. Prof. Dr. H. Baharuddin Lopa, SH., Majene Regency, \\ West Sulawesi,Indonesia \\ Telp.+6285379928222E-mail: rafiqa@unsulbar.ac.id
}

\begin{abstract}
The Objective of the research:to get information about the English vocabulary acquisition of the seventh, the eight and the ninth grade of students of state junior high school 2 Parepare. The researcher applied cross-sectional design to investigate differences between participants that vary by grade. The research population were all pupils who learned English, so the population of this research were students of State Junior High School 2 Parepare. They are the seventh grade which consist of 210 students, eight grade which consist of 208 students, and ninth grade consist of 234 students. The total number of population are 652.The researcher took sample from each grade by using random sampling technique. At the seventh grade consist of 36 students, at the ninth grade consist of 34 students, and the ninth grade consist of 32 students, so total number of sample are 102.

The result of this research showed that mean score of each grade were different. Mean score of seventh grade were 6,0778, it was lower than eight grade and ninth grade. Mean score of eight grade were 8,1088 means that it was in the middle between seventh and ninth group. And then mean score at ninth grade were 9,2500, it was a higher mean score than eight grade and seventh grade. Based on mean score from students of each grade showed that students of higher grade would they have higher vocabulary size.
\end{abstract}

Keywords: vocabulary dan English acquisition

\section{Introduction}

Vocabulary is one of the problems confronted by English language learners. Because of the limited vocabulary, the learners cannot communicate to others clearly. Vocabulary is one important aspect in learning a foreign language. With a limited vocabulary anyone will also has a limited understanding in terms of speaking, reading, listening, and writing. It is true that it might be impossible to learn a language without mastering vocabulary. Sometimes it is difficult to group the idea transmitted to 
them. The acquisition of a large number of vocabularies can help the students read, speak, listen, and write. Building vocabulary is extremely important for success in learning English.

Vocabulary acquisition is a key component to successfully developingcommunication and literacy skills. Developing a rich vocabulary is a top priorityand an on-going challenge for both first language and second language instruction. Whereas first language (L1) students arrive at school with a command of 2,000 to 6,000 words, most immersion studentsbegin their academic experience at point zero.

Once in the academic setting, immersion students are exposed to a great amount of vocabulary in a myriad of subject areas. They are required to use a fair amount of vocabulary throughout the day, acquiring a much larger vocabulary in the target language than students in traditional second language learning settings. Yet, due to the intense focus on content in the immersion setting and a lack of systematic vocabulary instruction, most immersion students' vocabulary knowledge is insufficient for quality, age-appropriate expression and literacy development in the upper elementary and secondary levels. This lack of a much larger active and passive vocabulary impacts two vital areas of their academic endeavors. A limited active vocabulary makes it difficult for students to express higher level complex thoughts, opinions or concepts. Limited passive vocabularies make it difficult for students to comprehend age-appropriate or subjectappropriate readings in the immersion language.

Learning vocabulary is an ongoing process that takes time and practice. Nakata (2006, p. 9) acknowledged that vocabulary acquisition requires continual repetition in order for effective vocabulary learning. Vocabulary acquisition is not something a student can spend time learning or memorizing, like grammar, and be successful. Acquisition requires the learner to be disciplined,spending time each day working on words he/she does not know in order for learners to remember high frequency words and put them into their long term memory, Nation and Waring stated that learners need to encounter the word multiple times in authentic speaking, reading, and writing context at the student's appropriate level.

It is important that a word is understood before it is used. This is important for both first and second language learners. This includes learning how to pronounce, written and how to spell a word that is first heared. Learning a second language attempts to create a parallel vocabulary to thefirst language. In the 19th century and in many parts of the world today, importance is placed upon grammar and structure when learning a new language. The importance of vocabulary acquisition has only more recently been recognized. Another stumbling block in second language vocabulary acquisition is the first language. This not only causes confusion in structure, but can also cause confusion in vocabulary.

The fact that individuals differ in their vocabulary knowledge may result in successful and unsuccessful text comprehension. Researchers in Englishvocabulary acquisition and use may agree that English vocabulary knowledge is essential in English language text comprehension (Laufer, 1997; Nassji, 2003; Nation, 2001; Read, 2000). English language learners who have limited vocabulary knowledge are less likely to be able to 
develop advanced levels of reading, listening, writing and speaking skills in the target language. Given the important role of vocabulary in language learning, researchers now investigate efficient ways and ideal environments to enhance vocabulary learning.

This research investigatedthe problem: What is the English vocabulary size of the seventh, the eighth and the ninth grade students of State Junior High School 2 Parepare?. Related to the problem above, the objective is to get information about the English vocabulary size of the seventh, the eighth and the ninth grade of students of state junior high school 2 Parepare.

Thescope in this research focused on english vocabulary acquisition of the students at seventh grade, eighth grade and ninth grade. The researcher investigated the English vocabulary size at the seventh, the eighth and the ninth grade during they study at Junior High School for 2015 academic year. The researcher conducted this research at state junior high school 2 Parepare.

\section{Previous Related Findings}

Jensen (1980, 146-147) states that children of high intelligence acquire vocabulary at a faster rate than children of low itelligence, and as adults they have a much larger vocabulary, not primarily because they are capable of they have spent more time in study or have been more exposed to words, but because they are capable of educing more meaning from single encounters with words. Adults had acquired vocabulary because they have spent more time to learn vocabulary.It is possible if the students at high grade will acquire many vocabularies than the students at low grade.

Nick C. Ellis (1995, p. 15-16) found that it is clear that it truly matters what learners do in order to acquire the meaning of a new word. Successful learners use sophisticated metacognitive knowledge to choose suitable cognitive learning strategies appropriate to the task of vocabulary acquisition. These include: inferring word meanings from context, effective use of dictionary and semantic or imagery mediation between the foreign language word and the first language translation, and deep processing for elaboration of the new word with existing knowledge.

The Eurocentre's Vocabulary Size Test (Meara \& Jones in Jame Milton 2009, p. 152), which is auto-adaptive, tests about 150 words, and forms an estimate of a learner's knowledge of the most frequent 10,000 words. X-Lex tests 120 words, 20 randomly selected words from each of Measuring Vocabulary Breadth: Passive Recognition Vocabulary 73 the first five 1000 word frequency bands and a further 20 pseudowords. The number of "Yes"responses to these pseudo-words allows the score on the real words to be adjusted for guessing and over-estimation of knowledge. A learner's vocabulary knowledge is calculated by counting the number of "Yes"responses to real words and by multiplying this by 50 to give a raw score out of 5000. The number of "Yes"responses to pseudowords is then calculated and multiplied by 250 . This figure is deducted from the raw score to give an adjusted score, also out of 5000, which thus includes a compensation for guesswork.

In a study of 172 Korean students, Kim and Gilman (2008, p.54) reported that information presented with visual text and supplementary graphics, or with visual text supplemented by spoken text and graphics could facilitate students' vocabulary acquisition the best.Based on these findings shows that the students will acquire 
vocabulary easly by using media to support english teaching learning process.

Lu-fang Ling (2010, p. 64-63) found that first, the video-based CALL program facilitates vocabulary incidental acquisition of students with different English proficiency abilities. Second, when viewing the videobased CALL program, students with proficient English reading and listening skills outperform those who are not proficient in the two skills in vocabulary learning. In general, participants proficient in only one area could not acquire significantly more vocabulary than those proficient in both reading and listening. His research result shows that English reading and listening proficiency plays a role in incidental acquisition of general vocabulary. RHLH (Reading High and Listening High) participants scored significantly more points than RLLH (Reading Low and listening High) participants in the recognition of total vocabulary.Students with different English proficiency abilities so will have difference in acquiring vocabulary also. If the students have english proficiency abilities so they will acquire many vocabularies.

Nation and Waring (1997, p. 7) reported that 5-year-old native English speakers beginning school will have a vocabulary of around 4,000 to 5,000 word families, adding roughly 1,000 word families a year until graduating from university with a vocabulary of around 20,000 word families.It is different when the children or students not native speaker, but English is foreign language for them. May the students or children will start to aquire english vocabulary at elementary school so they will learn bit by bit english vocabulary. It is supported by Takac's research, He (2008, p. 11)states that the secondlanguage acquisition refers to both the language acquired in the environment where the target language (English) is the language of communication and to the language acquired in the environment where the target language (English) is not used for communication.

\section{English Vocabulary Acquisition}

Second language or foreign language acquisition (Rod Ellis, 1997, p.3) can be define as the way in which people learn a language other than mother tongue, inside or outside of a classroom, and Second Language Acquisition (SLA) as the study of this. It has not focused on thesecommunicative aspects of language development but on the formal features of language that linguists have traditionally concentrated on.

Vocabulary acquisition concerns how people expand the number of words they understand when learning a new language, this includes both first and second language acquisition. Vocabulary refers to words and is divided into two types: functional words that perform a role in grammar and lexical words that provide information. The expansion of the mental lexicon is related to, but not part of, grammar and syntax acquisition. (Krashen, 2002, p. 89)A child's vocabulary acquisition falls into the longrunning debate over nature and nurture. Nature theory (Paul Nation and Ron Carter, 1989, p. 37) means children were born with certain linguistic tools, while nurture asserts that all tools are handed down from the people around the child as it grows up. Noam Chomsky(2001, 21) believes that children are given basic syntax and structure tools before they are born and use these tools to make sense of the words they learn from their environment.

Linguists are agreed that vocabulary acquisition is 100percent nurture (Paul Nation and Ron Carter, 1989, p. 39). If nature provided children with an inbuilt 
vocabulary, then the child have been speak the language of his or her parents or all children would be pre-programmed with the same proto-language. This is clearly not the case, so studies into vocabulary acquisition focus on how children learn words (Rod Ellis, 1997, P. 5).

English vocabulary acquisition is different from mother tonguevocabulary acquisition because an English learner has already developed conceptual and semantic systems linked to the mother tongue. This is why English vocabulary acquisition, at least in its initial stages, often involves a mapping of the new lexical form onto an already existing conceptual meaning or translational equivalent in first. The role of mother tongue in this process varies depending on the degree of equivalencybetween languages: although in some cases it may facilitate theacquisition or use of English language lexical items, in others it will create an obstacle.

This may occur in the process of acquisition, in recalling and using previously learnt lexical items, or in attempts of constructing a complex lexical item that has not been learnt as a unit. By making crosslinguistic comparisons (i.e. by contrastive analysis) one can often predict difficulties caused by interference of the mother tongue that learners may encounter when learning the English language.

Learning new English vocabularyis a complicated process involving a variety ofsub-processes and tasks. Before a word becomes a part of one's automaticlinguistic competence, it has to be recognized as a word, its morphosyntactic and semantic properties have to be learned, and it has to be integrated into one's mental lexicon so that it can be retrieved automatically when needed. One can view English vocabulary acquisition as encompassing two dimensions, The artsdimension is primarily concerned with the status of a lexical entry in the mental lexicon, i.e., the retention, consolidation, and automatization of words in the lexicon. Examples of the processes included in this dimension are the initial registration of a word in one's memory, the consolidation or loss of aword as a function of the learning strategies used and frequency of use and practice, the conversion of passive knowledge to productive skills, and theintegration of lexical knowledge into one's automatic competence. This dimensionis related to the aspects of vocabulary acquisition often referred to assize or breadth (Goulden, Nation, \& Read 1990).Most English vocabulary acquisition studies have focused on the retention dimension, i.e., on how new word retention is a ected by various factors (e.g. Brown \& Perry 1991).

The acquisition of decoding skills leads to rapid expansion of literate vocabularies by allowing children to transcode their meaning vocabularies into their literate vocabularies. This is so much the case that for older students and for adults our literate vocabularies are probably larger than our meaning vocabularies. We tend to have a larger group of words that we use in reading and writing than we use in our own speech. This is because written language is more formal, more complex, and more sophisticated than spoken language.

An important source of English vocabulary is a wide range of contexts. Learners can learn lexical items if they are exposed to sufficient amounts of comprehensible input. Nagy (1997) claims that an average second language learner can learn to recognise up to 1000 words a year from written materials. As has already been 
stated, the role of the context in initial stages of learning is limited, but its significance grows as the learner's knowledge expands. An ideal source for learning second vocabulary from context is reading (Ellis, 1997), becauselow-frequency lexical items (the ones that are characteristic of individuals with a wide vocabulary) occur more frequently in written than in spoken language. Besides, the learner has more time at his or her disposal for analysis, hypothesis testing and inferencing if working on a written text. Context-based inferencing contributes to the knowledge of morphological rules, collocations, additional meanings (for it is the context that determines the meaning of a lexical unit), etc. However, mere exposure during reading does not guarantee a rapid vocabulary growth. In order to accelerate the process, the learner must have critical strategic knowledge that will enable him or her to turn the incidental learning into an explicit learning process.

\section{a. Aspects of Vocabulary Acquisition}

Vocabulary acquisition is a process that depends on certain aspects which are psychological, biological, and social. These aspects determine the level and quality of acquisition and each related to one another.

1) Psychological Aspects, this aspects is marked along with the birth of one subdicipline of linguistics that is psycholinguitics. Psychological aspects of acquisition is a mental and behavioural features that underliethe acquisition. The children begin to understand their intention step by step before moving to use possible phonetic, lexical, and morphological variants in communication (Nick C. Ellis, 1995, p. 34). This aspects consider the basic of human soul of mind, will, and emotions that allow sender, channel, and recipient from communicative interaction (Volkova, 2012, p.30).

2) Biological Aspects. This aspects concerns critical period of acquisitio that a child must be exposed to language input. This aspects limits the brain for language acquisition from age two to puberty and the process which this factors take place is called lateralization (Lenneberg in Abidin, 2013 p.28).

3) Social Aspects. This aspect concern the possibility of vocabulary acquisition through social interaction. Vocabulary acquisition is considerd as social phenomenon; children try to acquire vocabulary by dealing with locally organized and sequentially structured discourse activities (Doehler and Ziegler, 2007, p.85).

All aof the third aspects above affect the vocabulary acquisition of human beings whereve they live.

b. The Process of Vocabulary acquisition: Two Alternative Hypotheses

Krashen states that there are two hypotheses of process vocabulary acquisituion (1998, p. 4), namely:

1) An implicit vocabulary learning hypothesis holds that the meaning of a new word is acquired totally unconsciously as a result of abstraction from repeated exposures in a range of contexts. Krashen input hypothesis that students acquire language by understanding messages: "language is subconsciously acquired - while you are acquiring, you don't know you are acquiring; your conscious focus is on the message, not form. Thus, the acquisition process is identical to what had been termed 'incidental learning.' Also acquired knowledge is represented subconsciously in the brain. Implicit 
learning is acquisition of knowledge about the underlying structure of a complex stimulus environment by a process which takes place naturally, simply and without conscious operations.

2) An explicit vocabulary learning hypothesis holds that learners' acquisition of new vocabulary can be strongly facilitated by the use of a range of metacognitive strategies: (i) noticing that the word is unfamiliar, (ii) making attempts to infer the word from context (or acquiring the definition from consulting others or dictionaries or vocabularies), (iii) making attempts to consolidate this new understanding by repetition and associational learning strategies such as semantic or imagery mediation techniques. Krashen (1998), it does not follow that vocabulary has been subconsciously acquired from the fact that we have not been taught the vast majority of the words that we know. That we have not been taught vocabulary does not entail that we have not taught ourselves. If this position holds then CALL (Computer Assissted Language Learning) has a considerable role to play.

\section{The development of vocabulary}

Vocabulary development is a process by which people acquire words. Babbling (in Willis, 1987. P.91) shifts towards meaningful speech as infants grow and produce their first words around the age of one year. In early word learning, infants build their vocabulary slowly. By the age of 18 months, infants can typically produce about 50 words and begin to make word combinations. In order to build their vocabularies, infants must learn about the meanings that words carry. The mapping problem asks how infants correctly learn to attach words to referents. Constraints theories, domain-general views, socialpragmatic accounts, and an emergentist coalition model have been proposed to account for the mapping problem. From an early age, infants use language to communicate. Caregivers and other family members use language to teach children how to act in society. In their interactions with peers, children have the opportunity to learn about unique conversational roles. Through pragmatic directions, adults often offer children cues for understanding the meaning of words.

Throughout their school years, children continue to build their vocabulary. In particular, children begin to learn abstract words. Beginning around age 3-5 (Willis, 1987) word learning takes place both in conversation and through reading. Word learning often involves physical context, builds on prior knowledge, takes place in social context, and includes semantic support. The phonological loop and serial order short-term memory may both play an important role in vocabulary development.

However, it seems important to point out that in almost all cases there are some differences in the number of words that an individual understands and uses. Even the terms "uses" and "understands" need clarification. For example, the major way in which we "use" vocabulary is when we speak and write; the term expressive vocabulary is used to refer to both since these are the vocabularies we use to express ourselves. We "understand" vocabulary when we listen to speech and when we read; the term receptive vocabulary is used to refer to listeningand reading vocabularies. Finally, to round out the terminology, meaning or oral vocabulary refers to the combination of listening and speaking vocabularies, and literate 
vocabulary refers to the combination of our reading and writing vocabularies.

Figure 1

Vocabulary

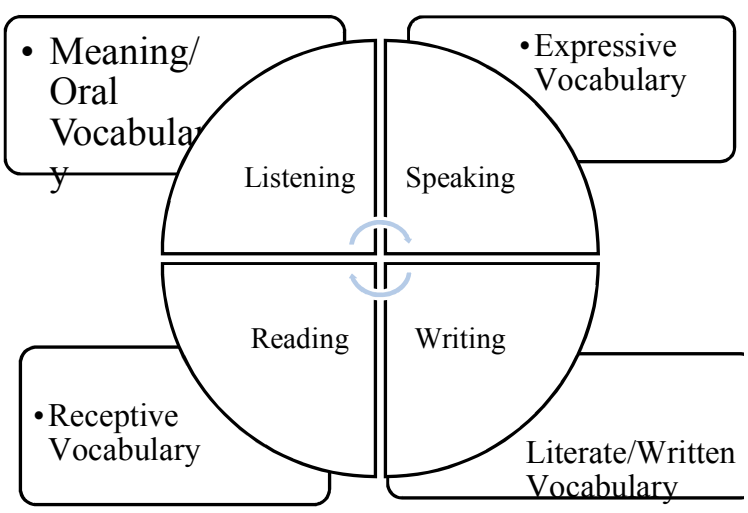

Figure 1 shows the relationship of the eighth different terms, namely: listening, reading, speaking, writing, meaning/oral vocabulary, expressive vocabulary, literaste/written vocabulary, and receptive vocabulary. For the first five years, children are involved in the process of acquiring a meaning/oral vocabulary that they understand when they hear it and that they can use in their speech. Most children acquire reading and writing skills upon entering school. They need to acquire a basic knowledge of how printed letters relate to the sounds of spoken words and how printed words relate to spoken words. Being able to translate into speech allows children to use what they know about meaning/oral vocabulary for their literate vocabulary. So for very young children, their meaning vocabularies are much larger than their literate vocabularies.

Children learn language and increase their vocabulary in only one way-listening to the people around them. The richer and more abundant the language they hear daily, the more well developed their own language will be. In addition to normal conversation, however parents dozens of creative and enjoyable ways to increase childrens' vocabularythat can also build family bonds and heighthen family fun.

There some ways that can develop childrens' vocabulary, namely:

a. Read aloud. Of course many people have been reading aloud to their children since he was born, but try reading books with charactes and plots. Take time for discussion point out new words and concepts to children

b. Show and tell. Whereever parents go somewhere, collect something to bring back. Have a show and tell time when the family is together. Give children the floor to tell about their treasure. These special objects need not be expensive or elaborate. The important part is sharing information and experiences.

c. Talk. Never understimate the importance of good conversation and information to the development of vocabulary.

d. Label, label, and label. Give the children as much vocabulary as you parents can. They will probably remember the big words easily because shorter words with similar letters such as "was" and "saw" and "which" and "when" are confusing. Most preschoolers know all the names of dinosaurus that most adults can barely pronounce. Their minds are like sponges.

Vocabulary development does not stop once a child can talk.in fact, children learn many new words once they start reading and going to school. There are typical vocabulary development across several ages. Notice how quickly vocabulary grows over the first six years of live. Age 1 to $1 \frac{1}{2}$ years old, toddlers develop around a 20 -word vocabularyduring the time. Age 2 
years old, by the time a child is 2 years old, he/she will have a 200-300 words. Age 3 years old, vocabulary grows to be about 900 1000 words. Age 4 years old, the typical child will have about a 1500-1600 word vocabulary. Age 5 years old, by the time a child reaches school age and heads to kindergarten, he/she will have between a 2100-2200 words vocabulary. Age 6 years old, the child typically has a 2600 words expressive vocabulary, and receptive vocabulary of 20000-24000 words. Age 12 years old, by the time a child is 12 years old, he/she will understand of 50000 words (Susie Loraine, p.149)

\section{Measuring Vocabulary Breadth}

Some of the best-researched tests of vocabulary are checklist tests of passive vocabulary recognition, designed to give an estimate of vocabulary breadth or size. Passive recognition is likely to be the most basic, catch-all definition of word knowledge; the learner recognises the form of a word and that it is a word rather than a meaningless jumble of symbols or sounds. Every other quality of knowing ought to fall within such an estimate, as you cannot translate or know details of collocation for a word you cannot even recognise as a word. The format of checklist tests is deceptively simple. The learner is presented with a series of words and is asked to tick the ones they know or can use.

There is no perfect testing method of course and this checklist methodhas its advantages and disadvantages (James Milton, 2009 , p.53). The advantages include the relative speed and ease with which these tests can be constructed provided a suitably constructed frequency list is available. It is possible to test a large number of words, compared to other testing methods, relatively quickly. The results are likely to be more reliable both because a larger sample size is always likely to give better results than a smaller sample, and because the test can be relatively brief and there is less opportunity for learners to become bored and lose concentration. The test usually selects words from across the frequency bands and this format also has an enormous benefit in that it is possible to quickly and easily create multiple versions of the test, with different words selected from the frequency bands, which should perform the same way. It is not uncommon for the correlations in the high 0.9 's to emerge where scores taken from tests using different selections of words are compared (e.g. Adamopoulou, 2000). David (2008a) uses three versions of this test (with different words included) in her research in order to prevent students copying each other. She concluded there was no significant difference in the results obtained from the three versions (ANOVA results: $\mathrm{F}(2$, 480)_0.332, p_0.717).

The disadvantage is the degree to which learners are able to guess, when they do not really recognise a word or are not sure. Earlier, Please look at these words. Some of tests include a not sure category to help separate out words like this. More usually, false words are often included in such tests to allow compensation for this kind of uncertainty, and for outright guesswork. False words are words constructed to read and sound like real words, but which do not really exist. Eyckmans et al. (2007), in a study of Belgian learners, reports huge amounts of over-estimation; up to $60 \%$ of false words were, on average, identified as real. Part of the problem identified is to do with response bias, which is the tendency for people, faced with Yes/No questions ofthis type, to answer Yes regardless of the question. But this cannot explain the 
tendency of this group to say Yes to almost everything and one wonders just how seriously the learners took the test. It provides a warning, however, that not all tests may work equally well with all learners, and if the learners are unwilling or unable to interact with the test in the way we expect, then the data they provide may be worthless.

The tests are deliberately constructed to give an estimate of vocabulary size, within strict frequency limits, and would seem very suitable for measurements that seek to assess vocabulary growth over time. One is the Eurocentre's Vocabulary Size Test (Meara \& Jones, 1990), which is auto-adaptive, tests about 150 words, and forms an estimate of a learner's knowledge of the most frequent 10,000 words. X-Lex (Meara \& Milton, 2003 ) tests 120 words, 20 randomly selected words from each of

Measuring Vocabulary Breadth: Passive Recognition Vocabulary 73 the first five 1000 word frequency bands and a further 20 pseudo-words. The number of Yes responses to these pseudo-words allows the score on the real words to be adjusted for guessing and over-estimation of knowledge. A learner's vocabulary knowledge is calculated by counting the number of Yes responses to real words and by multiplying this by 50 to give a raw score out of 5000. The number of Yes responses to pseudowords is then calculated and multiplied by 250 . This figure is deducted from the raw score to give an adjusted score, also out of 5000, which thus includes a compensation for guesswork. There is no time limit to the test, which generally takes only 5 or 10 minutes to complete.

A second, very widely used, type of test method in estimating vocabulary knowledge involves requiring learners to demonstrate that they know translations or explanations of foreign language words. Tests can be passive, and provide learners with translations or explanations to choose from, or rather more productive in requiring the learner to produce a foreign language word in response to a native language stimulus. In the literature, these two tests are known as recognition and recall tests.

Nation's widely used Levels Test (Nation, 1990, revised Schmitt et al., 2001) is an example of this type of recognition test where learners are provided with test words in the foreign language and a selection of explanations which must be matched up. There is an example vocabulary test.

This is a vocabulary test. You must choose the right word to go witheach meaning. Write the number of that word next to its meaning.

1 business

2 clock part of a house

3 horse animal with four legs

4 pencil something used for writing

5 shoe

6 wall

(Adopted by James Milton, 2009)

Djamiah (2011) recently reported speak aloud protocols conducted with learners taking this test. The feedback he received suggests that a considerable amount of guesswork and calculation goes on in answering this kind of question and that the learner's choice of guessing strategy can produce considerable differences in scores. The Levels Test might have much more variation according to guesswork than most users ever imagine. However, there is no explicit way in the test for taking account of this phenomenon or compensating for it.

The impact of standardised testing methods of this kind in measuring vocabulary breadth is potentially very considerable. It becomes possible to compare 
learning among different groups of learners in schools or in different countries in a way that could not be done before. It may even be possible to compare learning in different languages, as word counts, using the same kinds of counting method, can be done. This brings its own problems and difficulties, not least because languages can inflect, derive and combine words so very differently. It is not certain that knowing 1000 words in German, for example, will provide as much potential language competence as knowing the same number of words in English. Estimates of vocabulary knowledge in these different languages may tell us very different things about overall language knowledge and performance. Nonetheless, it becomes possible to attempt these investigations and to consider, in the light of the data that emerges, just how informative this kind of analysis is.

\section{Conceptual Framework}

Based on explanation above, the researcher presents a conceptual framework. The conceptual framework here consist ofEnglish vocabulary then students will acquire that vocabulary. Students acquire this vocabulary when they at seventh grade, at eighth grade and at ninth grade

Figure 2.

Conceptual Framework

EnglishVocabulary

Acquisition

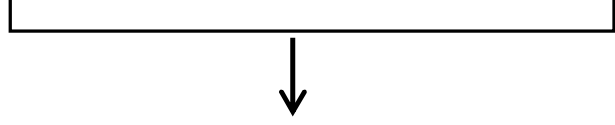

Students at 2013

academic year

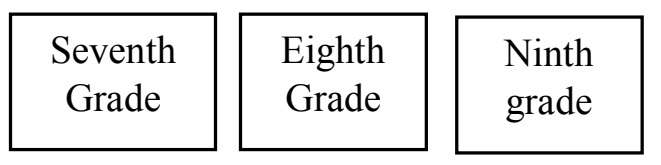

Vocabulary Acquisition Development

\section{RESEARCH METHOD}

This research is aimed at investigatingthe developmental differences or developmental change of English vocabulary acquisition of the students, so the general focus is quantitative developmental research.Actually, there are two designs used to make inferences about change over time namely cross-sectional design and longitudinal design (Atmowardoyo, 2010, p. 80). The researcher choosed one of two develompemntal research, researcher appliedcross-sectional design in this research. Cross-sectional designs investigate differences between participants that vary by grade depend on variable of interest. Usually, data from these studies are collected at one point in time and comparisons are made to reveal the developmental differences (Atmowardoyo, 2010, p.80).

\section{Population and sample of the Research}

The research population is all pupils who learnedEnglish, so the population of this research are students of State Junior High School 2 Parepare. They are the seventh grade which consist of 210 students, eighth grade which consist of 208 students, and ninth grade consist of 234 students. The total number of population are 652 .

The researcher took $20 \%$ of each grade by using random sampling technique, so the researcher took $60 \%$ as sample from total number of population. At the seventh grade consist of 36 students, at the ninth grade consist of 34 students, and the ninth grade consist of 32 students, so total number of sample are 102.

\section{Instrument of the Research}

The instruments had beenused in this research to collect the data is vocabulary test. 
The vocabulary test is aimed at gaining data of the students. It can be used to measure the students vocabulary acquisition. Vocabulary test consist of 100 items.

\section{Procedure in Collecting Data}

The researcher collected the data by using vocabulary test. The researcher gave the test to the students three times. The first time, researcher gave vocabulary test at seventh grade, second time, vocabulary test conducted at eighth grade, and the third time, vocabulary test conducted at ninth grade.

Data Analysis technique

The Analysis of the data in this research was done statistics pocedures. The procedures consist of clasification of students' score, the sum number and One way ANOVA. The researcher used one way anova because in this research there were three independent variables. Their score can be compared to the scores of a high level/grade to determine the developmental based on the grade. The data analyzed by following techniques:

1. Tabulating the score of the students test.

$$
\text { Score } \frac{\text { students' }^{\prime} \text { correct answer }}{\text { the total number of test }} \times 10
$$

2. Classification of the score

Score of students' value will be classification based on the following classification:

Table 2.

Classification of Score

\begin{tabular}{|c|c|c|}
\hline Num. & Classification & Range of score \\
\hline 1 & Excellent & $9,1-10$ \\
2 & Very Good & $8,1-9,0$ \\
3 & Good & $7,1-8,0$ \\
4 & Fair & $6,1-7,0$ \\
5 & Poor & $5,1-6,0$ \\
6 & Very Poor & $<5,0$ \\
\hline
\end{tabular}

Source: (Depdiknas, 2004)

3. Calculating the students' score into percentage by using the formula:

$$
\mathrm{P}=\frac{\mathrm{Fq}}{\mathrm{N}} \times 100
$$

Where:

P : Percentage

$\mathrm{Fq}:$ : number of Frequency

$\mathrm{N}$ : The number of the students.

(Sugiono, 2009, p.48)

4. Calculating the mean of the totals score of the students by using formula as follow:

$$
\bar{X}=\frac{\sum X}{N}
$$

Where:

$\overline{\mathrm{X}} \quad$ : Mean score

$\sum X \quad$ : The sum of the score

$\mathrm{N}$ : The number of the subject.

(Baso Jabu, 2008: 26)

5. Calculating the standard deviation by using formula as follow:

$$
\mathrm{Sd}=\sqrt{ } \sum \mathrm{d}^{2}
$$

The Procced as follow:

a. Finding out the amount by which each score deriviates from the mean $(d)$

b. Square each result $\left(\mathrm{d}^{2}\right)$

c. Add up all the result $\left(\sum \mathrm{d}^{2}\right)$

d. Divide the total by number of testtees

e. Find the square root of this result (Baso Jabu, 2008, p.117-118)

6. The Data Analysis

ANOVA (Analysis of Variances) is used to conduct comparative analysis with multivariables. This research used ANOVA to analyze three independent variables. 


\section{RESULTS AND DISCUSSION}

\section{The Students' English Vocabulary Size}

This section deals with the presentation and explanation of data about vocabulary size of the students of State Junior High school 2 Parepare at seventh grade, eighth grade, and ninth grade.

Based on the findings, the researcher found that the students' vocabulary at State Junior high school 2 Pareparerelated to the levels of words (Takac, 2008, p. 39), it shows that at seventh grade was in the level I words, and at eighth grade was in level I words and level II words, and then at ninth grade was in level I words, level II words and level III words.

a. Classification of students' vocabulary score

As being stated earlier that after correcting and scoring the students' result test, then the researcher tabulating that data into classification score into percentage. The the data were classified into 6 (six) levels based on Depdiknas (2004) classification, namely: excellent, very good, good, fair, poor, and very poor. The following table shows the frequency and the rate percentage of the students State Junior High School 2 Parepare on each grade.

Table 3.

Classification Score of the Students of

\begin{tabular}{|c|c|c|c|c|c|c|c|c|}
\hline \multicolumn{4}{|c|}{$\begin{array}{l}\text { Classification Score of the Students of } \\
\text { Seventh Grade }\end{array}$} & 4 & Fair & 6.1 & \multirow{2}{*}{4} & \multirow{2}{*}{11.8} \\
\hline \multirow{2}{*}{ Numb. } & \multirow{2}{*}{ Classification } & Range of & $\Gamma$ & & Persentage & 7.0 & & \\
\hline & & Score & Fiеquy & $\omega y$ & $(\%)$ & 5.1 & \multirow{3}{*}{2} & \multirow{3}{*}{5.9} \\
\hline 1 & Excellent & $9.1-10$ & - & 5 & Poor & - & & \\
\hline 2 & Very Good & $8.1-9.0$ & 7 & & 19.4 & 6.0 & & \\
\hline 3 & Good & $7.1-8.0$ & 4 & \multirow[b]{2}{*}{6} & 1N.ery & $<$ & \multirow{2}{*}{2} & \multirow{2}{*}{5.9} \\
\hline 4 & Fair & $6.1-7.0$ & 4 & & 1 P.dor & 5.0 & & \\
\hline 5 & Poor & $5.1-6.0$ & 9 & & 35 otal & & \multirow{2}{*}{34} & \multirow{2}{*}{100} \\
\hline 6 & Very Poor & $<5.0$ & 12 & & 33.4 & & & \\
\hline & Total & & \multicolumn{6}{|c|}{36 (sounce: result of pocabulary test at eighth } \\
\hline
\end{tabular}

(source: result of vocabulary test at seventh grade)

Based on the table above, shows that the score analyzed classification of 36 students at seventh grade, there were none students got excellent classification, there were $7(19.4 \%)$ students gotvery good classification, there were $4(11.1 \%)$ students got good and fair classification, there were 9 $(25 \%)$ students got poor classification, and there were 12 (33.4) students got very poor classification. This result shows that there were many students domination at low score and there were not students had high score, it means that the students at seventh grade had low vocabulary size.

Table 4.

Classification Score of the Students of Eighth Grade

\begin{tabular}{|c|c|c|c|c|}
\hline $\begin{array}{l}\text { Num } \\
\text { b. }\end{array}$ & $\begin{array}{c}\text { Classifica } \\
\text { tion }\end{array}$ & $\begin{array}{c}\text { Ran } \\
\text { ge } \\
\text { of } \\
\text { Scor } \\
\text { e }\end{array}$ & $\begin{array}{c}\text { Frekue } \\
\text { ncy }\end{array}$ & $\begin{array}{l}\text { Persent } \\
\text { age }(\%)\end{array}$ \\
\hline 1 & Excellent & $\begin{array}{c}9.1 \\
-10\end{array}$ & 14 & 41.1 \\
\hline 2 & $\begin{array}{l}\text { Very } \\
\text { Good }\end{array}$ & $\begin{array}{c}8.1 \\
- \\
9.0\end{array}$ & 7 & 20.6 \\
\hline 3 & Good & $\begin{array}{c}7.1 \\
- \\
8.0\end{array}$ & 5 & 14.7 \\
\hline 4 & Fair & $\begin{array}{c}6.1 \\
-\end{array}$ & 4 & 11.8 \\
\hline dncy & Persentage & 7.0 & & \\
\hline & $(\%)$ & 5.1 & & \\
\hline 5 & $\begin{array}{c}\text { Poor } \\
19.4\end{array}$ & $\begin{array}{c}- \\
6.0\end{array}$ & 2 & 5.9 \\
\hline 6 & $\begin{array}{l}1 \text { k.ery } \\
1 \text { p.dor }\end{array}$ & $\begin{array}{c}< \\
5.0\end{array}$ & 2 & 5.9 \\
\hline & $\begin{array}{c}55 \text { tal } \\
33.4\end{array}$ & & 34 & 100 \\
\hline
\end{tabular}


Based on the table above, shows that the score analyzed classification of 34 students at eighth grade, there were 14 (41\%) students got excellent classification, there were $7(20.6 \%)$ students gotvery good classification, there were $5(14.7 \%)$ students got good, there were $4(11.8 \%)$ students got fair classification, there were 2 (5.9\%) students got poor classification and very poor classification. This result shows that there were many students $(41.1 \%)$ domination at high score it means that almost a half $(50 \%)$ of students had high score, but some of students still on middle and low score classification.

Table 5.

Classification Score of the Students of Ninth

\begin{tabular}{|c|c|c|}
\hline \multicolumn{3}{|c|}{ Grade } \\
$\begin{array}{c}\mathrm{Nu} \\
\mathrm{mb}\end{array}$ & Classification & Range of Score \\
\hline 1 & Excellent & $9.1-10$ \\
\hline 2 & Very Good & $8.1-9.0$ \\
\hline 3 & Good & $7.1-8.0$ \\
\hline 4 & Fair & $6.1-7.0$ \\
\hline 5 & Poor & $5.1-6.0$ \\
\hline 6 & Very Poor & $<5.0$ \\
\hline
\end{tabular}

Total

(source: result of vocabulary test at ninth grade)

Based on the table above, shows that the score analyzed classification of 32 students at ninth grade, there were 27 (84\%) students got excellent classification, there were $1(3.1 \%)$ students got very good classification, there were $2(6.3 \%)$ students got good, there were $1(3.1 \%)$ students got fair classificationand poor classification, and there were none students got very poor classification. This result shows that there were dominant students (84\%) at higher score it means that almost the students (more than 50\%) had high score, and there were not students hadlow score classification.

b. The Mean Score and Standard Deviation of Students' Vocabulary Size

The following table shows the result of the students' vocabulary score at seventh grade, eighth grade, and ninth grade. The table presented mean score of the students of each grade, standard deviation of each grade, standard error of each grade, confidence interval for mean from lower bound to upper bound, minimum score and maximum score of each grade.

Table 6.

The result of data analyzed

\begin{tabular}{|c|c|c|c|c|c|c|c|c|}
\hline \multirow{2}{*}{$\begin{array}{l}\mathrm{Na} \\
\mathrm{me}\end{array}$} & \multirow[b]{2}{*}{$\mathrm{N}$} & \multirow{2}{*}{$\begin{array}{c}\mathrm{M} \\
\mathrm{ea} \\
\mathrm{n}\end{array}$} & \multirow{2}{*}{$\begin{array}{l}\text { Std. } \\
\text { Devi } \\
\text { ation }\end{array}$} & \multirow{2}{*}{$\begin{array}{c}\text { Std. } \\
\text { Err } \\
\text { or }\end{array}$} & \multicolumn{2}{|c|}{$\begin{array}{l}95 \% \text { Confidence } \\
\text { Interval for Mean }\end{array}$} & \multirow{2}{*}{$\begin{array}{c}\mathrm{M} \\
\mathrm{in} \\
\mathrm{i} \\
\mathrm{m} \\
\mathrm{u} \\
\mathrm{m}\end{array}$} & $\begin{array}{l}\mathrm{M} \\
\mathrm{a}\end{array}$ \\
\hline & & & & & $\begin{array}{l}\text { Lower } \\
\text { Bound }\end{array}$ & $\begin{array}{l}\text { Upper } \\
\text { Bound }\end{array}$ & & $\begin{array}{c}\mathrm{i} \\
\mathrm{M} \\
\mathrm{u} \\
\mathrm{m}\end{array}$ \\
\hline $\begin{array}{c}\text { VII } \\
\text { Gra } \\
\text { de }\end{array}$ & $\begin{array}{l}3 \\
6\end{array}$ & $\begin{array}{c}6 . \\
07 \\
78\end{array}$ & $\begin{array}{l}1.73 \\
602\end{array}$ & $\begin{array}{c}0.2 \\
893 \\
4\end{array}$ & 5.4904 & 6.6652 & $\begin{array}{l}2 . \\
60\end{array}$ & $\begin{array}{l}9 . \\
0 \\
0\end{array}$ \\
\hline $\begin{array}{c}\text { VIII } \\
\text { Gra } \\
\text { de }\end{array}$ & $\begin{array}{l}3 \\
4\end{array}$ & $\begin{array}{c}8 . \\
10 \\
88\end{array}$ & $\begin{array}{l}1.52 \\
561\end{array}$ & $\begin{array}{c}0.2 \\
616 \\
4\end{array}$ & 7.5765 & 8.6411 & $\begin{array}{l}3 . \\
70\end{array}$ & $\begin{array}{l}9 . \\
6 \\
0\end{array}$ \\
\hline $\begin{array}{c}\text { IX } \\
\text { Gra } \\
\text { de }\end{array}$ & $\begin{array}{l}3 \\
2\end{array}$ & $\begin{array}{c}9 . \\
25 \\
00\end{array}$ & $\begin{array}{l}0.98 \\
308\end{array}$ & $\begin{array}{c}0.1 \\
737 \\
9\end{array}$ & 8.8956 & 9.6044 & $\begin{array}{l}5 . \\
70\end{array}$ & $\begin{array}{l}1 \\
0 . \\
0 \\
0\end{array}$ \\
\hline $\begin{array}{c}\text { Tota } \\
1\end{array}$ & $\begin{array}{l}0 \\
2\end{array}$ & $\begin{array}{c}7 . \\
75 \\
00\end{array}$ & $\begin{array}{l}1.96 \\
326\end{array}$ & $\begin{array}{c}0.1 \\
943 \\
9\end{array}$ & 7.3644 & 8.1356 & $\begin{array}{l}2 . \\
60\end{array}$ & $\begin{array}{l}1 \\
0 . \\
0 \\
0\end{array}$ \\
\hline
\end{tabular}

The table shows that mean score of each grade were different from seventh grade to ninth grade. Mean score at seventh grade were 6.0778 , mean score at eighth grade were 8.1088 , and then mean score at ninth grade were 9.2500. The table shows that mean score of each grade were increasing from low grade to high grade, it can be seen from the chart below: 


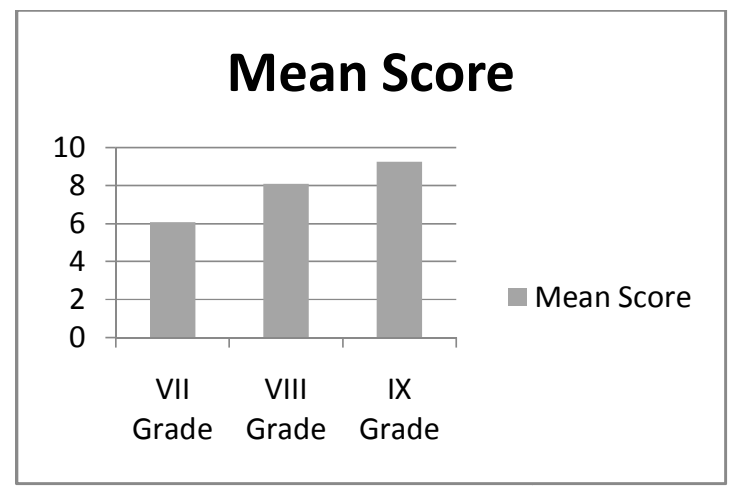

The graphichs above shows that the different and distance of students mean scores. The different grade made the students acquire different vocabulary also, this finding related to the research findings of Jensen (1980, 146-147) states that children of high intelligence acquire vocabulary at a faster rate than children of low itelligence, and as adults they have a much larger vocabulary, not primarily because they are capable of they have spent more time in study or have been more exposed to words, but because they are capable of educing more meaning from single encounters with words. It is possible if the students at high grade will acquire many vocabularies than the students at low grade.

Based on the table above shows that standard deviation seventh grade got 1.73602 , eighth grade got 1.52561 , and then ninth grade got 0.98308 . Standard deviation of the ninth grade were lower than the eighth grade and the seventh grade, and then seventh grade were higher standard deviation than the eighth grade and the ninth grade. The standard deviation of eighth grade were in the middle between the ninth and the seventh grade.

Table 6. shows that standard error of the students from each grade were different. The seventh grade got 0.28934 standard error, eighth grade got 0.26164 standard error and then ninth grade got 0.17379 standard error. The ninth grade were lower standard error from the seventh grade and the eighth grade. The seventh grade were higher standard error than the other grade. The eighth grade were in the middle level of standard error between seventh and ninth grade. The grade were more lowstandard deviation means that the data were homogeneous.

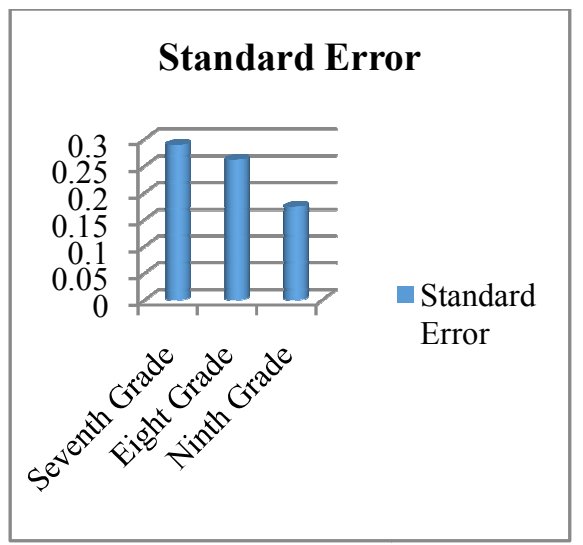

Table 6. shows minimum and maximum column. Minimum column means that students of each grade had lower score. Minimum score of The seventh grade were 2.60 score, minimum score of eighth grade were 3.70 score, and minimum score of ninth grade were 5.70 score. It means that the lower minimum score was seventh grade. The ninth grade got the higher minimum score than the other grade, based on the chart below:

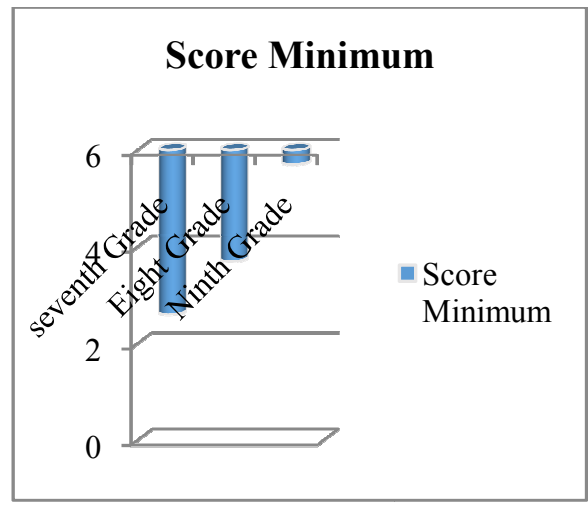

The column maximum on the table above shows that seventh grade got 9.00 maximum score, maximum score of eighth grade were 9.60 score, and then one student 
of the ninth grade got 10.00 score it means that it was a higher maximum score. The seventh grade had lower minimum score than the eighth grade, so that the maximum score of eighth grade were in the middle between seventh and ninth grade, based on chart below:

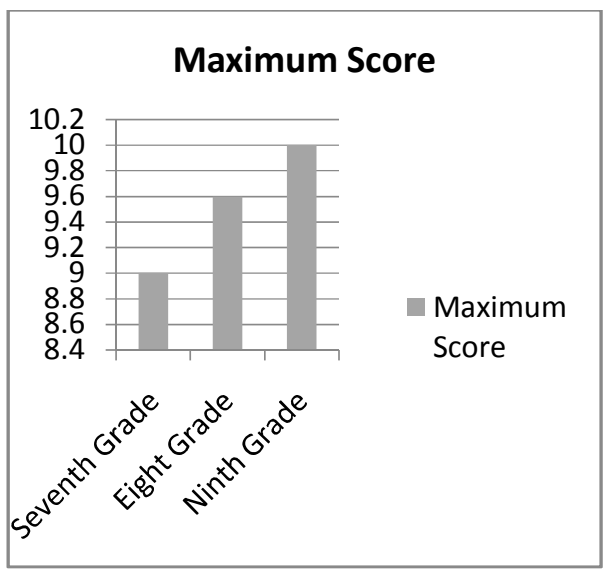

\section{Discussion}

In this discussion section, the researcher presented the interpretation result of the data analyzed. The result of this research in the discussion section related to some theories to support the findings.

Students classification score showed at table 3 that most of students at seventh grade got very poor $(33.4 \%)$ classification score. Classification score at table 4 for students at eighth grade were $41.1 \%$ got excellent, but the other students $(58.9 \%)$ spread on good, fair and very poor classification classification. Diffrent from students of seventh grade and eighth grade, almost all of the students of ninth grade at table 5 got excellent classification score and there were not students got very poor classification score. It means that score of each grade were increasing from low grade to high grade.

Mean score of each grade was different. Mean score attable 6 of seventh grade were 6.0778 , it was lower than eighth grade and ninth grade. Mean score of eighth grade were 8.1088 means that it was in the middle between seventh and ninth group. And then mean score at ninth grade were 92500, it was a higher mean score than eighth grade and seventh grade. Based on mean score from students of each grade showed that students of higher grade would they have higher vocabulary size.

There was the development vocabulary size between seventh grade and eighth grade, the students vocabulary was increasing. Vocabulary size of students at ninth grade were higher than the eighth grade, it means that it was increasing. It showed that students vocabulary size from low grade to higher grade were increasing. It was related to Jensen's research findings (1980, 146-147) states that children of high intelligence acquire vocabulary at a faster rate than children of low itelligence, and as adults they have a much larger vocabulary, not primarily because they are capable of they have spent more time in study or have been more exposed to words, but because they are capable of educing more meaning from single encounters with words.

Based on students' mean score showed that between seventh grade and eighth grade had long difference mean score, mean score between eighth grade and ninth grade was closed difference mean score. It means that seventh grade to eighth grade had gap development vocabulary size, while compared with eighth grade to ninth grade was relative closed.

There are many reasons or factors that can influence students vocabulary size development. James Milton(2009, p.172) suggest that vocabulary size might be expected to grow in size through the bands and that in the upper bands, include lexical 
depth might also be expected to develop. Assessors are expected tomake judgements of the range and scale of vocabulary the learner possesses and uses.Such an approach identifies potentially important age differences in children quickly and provides some insights into the specific problems children of different ages and abilities have.

The other reason that found by Nick C. Ellis (1995, p. 15-16) that it is clear that it truly matters what learners do in order to acquire the meaning of a new word. Successful learners use sophisticated metacognitive knowledge to choose suitable cognitive learning strategies appropriate to the task of vocabulary acquisition. These include: inferring word meanings from context, effective use of dictionary and semantic or imagery mediation between the foreign language word and the first language translation, and deep processing for elaboration of the new word with existing knowledge. In Takac's research, also found $(2008$, p. 11) that the secondlanguage acquisition refers to both the language acquired in the environment where the target language (English) is the language of communication and to the language acquired in the environment where the target language (English) is not used for communication.

It is possible that oldest students has higher vocabulary size than youngest students has low vocabulary size. It caused of many factors for example it was influenced by environment, the students who had studied for long time would get more experience or knowledge than the students who had studied for short time or still on process. Bloom (2002, p. 29) conclude that between the ages of 12 months and 18 years, children learn on average 10 words a day if they hear lots of new words used in their environment. He suggest that to develop vocabulary acquisition, a young child needs (1) exposure to new vocabulary, (2) self motivation and engagement; (3) multiple exposure to new words that give contextual and definitional information, (4) the use of independent word learning strategies. It is important for children develop knowledge of words from young age because vocabulary development has an impact on their reading comprehension and academic success as they get older.

\section{CONCLUSION}

Based on the findings and discussion, the result of this research conclude that:

Vocabulary size of each grade was diffrent. Students at seventh grade got mean score 6.0778, students at eighth grade got mean score 8.6411, and then students at ninth grade got higher mean score 9.6044. It means that the students at low grade have low vocabulary size and students at high grade have high vocabulary size than low grade.

\section{REFERENCES}

Atmowardoyo, Haryanto. 2010. Research Methods for Language and Literature studies. Makassar: The Universitas Negeri Makassar.

Ellis, Rod. 1997. Second Language Acquisition. New York: Oxford University Press.

Ellis, Nick C. 1995. The Psychology of FL Vocabulary Acquisition; Implications for CALL.. International Journal of Computer Assisted Language Learning (CALL). Accessed on July $2^{\text {th }}, 2013$

Fuente, Maria J. de la. 2006.Classroom L2 vocabulary acquisition: investigating the role of pedagogical tasks and 
form-focused

instruction

USA;Vanderbilt University.

Hadfied, Jill. 2002. Elementary Vocabulary Games. England; Longmand.

Harmer, Jeremy. 1991, The Practice of English Language Teaching, Singapore; Longman.

Ho, Hsiu-Zu. 2006. Handbook of Complementary Methods in Education Research. Laurence Erlbaum Assosiates Publisher, London

Jabu, Baso. 2008. English Language Testing. Makassar; The UNM Publisher.

Krashen, Stephen D. 2002. Second Language Acquisition and Second Language Learning. California; University of Southern. ,1981. Principles and Practice in Second Language Acquisition. California; University of Southern. , 1998, We Acquire Vocabulary and Spelling by Reading: Additional evidence for the input Hypothesis.California; University of Southern.

Lu-Fang Lin. 2010. English Learners" Incidental Vocabulary Acquisition in the Video-based CALL Program. Asian EFL Journal. Special Issue. volume 12 , issue 4 . http://www.asianefl-journal.com..

Meara, Paul. 1991. Connected Words. Word associations and second language vocabulary acquisition. Amsterdam; John Benjamins Publishing Company.

Milton, James. 2009. Measuring Second Language Vocabulary Acquisition. Library of Congress Cataloging in Publication Data

Nation, Paul and Ron Carter ,1989.Vocabulary Acquisition.

England; University of nottingham.
Nunan, David. 1989, Design Task for the Communicative classroom, New York; Cambridge University Press.

Sugiono. 2005, Statistika Untuk Penelitian. Bandung; Alfabeta.

Takac Vavicic, Visnja. 2008. Vocabulary Learning Strategies and Foreign Language Acquisition. Library of Congress Cataloging in Publication Data.

Willis, Jane. 1987, Teaching English Through English, England; longman.

Zulfah, 2007. The Teaching of English at Elementary School in Makassar (A case study at SDN Unggulan Toddopuli Makassar). Unpublish Thesis. Makassar: UNM. 